https://doi.org/10.15407/scine17.04.072

TSURKO, E. N.' (https://orcid.org/ 0000-0001-8909-4071), and KUNZ W. ${ }^{2}$ (https://orcid.org/0000-0002-9463-632X)

'Research Institute for Chemistry, Karazin National University, 4, Svoboda Sq., Kharkiv, 61022, Ukraine, +380 57707 5660; univer@karazin.ua

${ }^{2}$ Institute of Physical and Theoretical Chemistry, University of Regensburg, 31, Universitätsstr, Regensburg, 93053, Germany, +49941943 4044, registratur@ur.de

\title{
SALTING-IN AND SALTING-OUT EFFECTS OF POLYPHENOLS, AROMATIC COMPOUNDS, AND AMINO ACIDS ON POLY (N-ISOPROPYLACRYLAMIDE) AND EGG WHITE AQUEOUS SOLUTIONS
}

Introduction. Understanding the biophysical phenomena related to the Hofmeister series or cosmotropic/chaotropic properties of ions requires experimental data on specific ion effects of large organic molecules.

Problem Statement. Specific ion effects are of significant importance for biophysics and medicine. It is interesting to find out if additives with biologically relevant anions can interact with proteins and avoid aggregation.

Purpose. The purpose of this research is to study the stabilizing/destabilizing effects in Poly(N-isopropylacrylamide) (PNIPAM)/water, hen egg white/water systems under influence of substances of various classes of different hydrophobia.

Materials and Methods. Materials: sodium salts: salicylate, ferulate, benzoate, vanillate, cinnamate; humic acid sodium salt, hydroxy-sodium benzoate, glycine, L-alanine, sodium L-glutamate, D-(-)-quinnic acid, PNIPAM, egg white. Methods: measurement of the transition temperature (TT) of PNIPAM/water and the denaturation temperature of the egg white / water systems.

Results. Ion-specific effects have been studied with the use of models based on the research of the transition temperature (TT) evolution of binary PNIPAM / water mixtures (for heating from 0 to $35^{\circ} \mathrm{C}$ ) and the denaturation temperature of the egg white / water (for heating from 48 to $65^{\circ} \mathrm{C}$ ). The dependences of these temperatures on the content of substances that occur in live nature have been received at $p H=7.4$.

Conclusions. The results have shown the tendencies of the additive solubilizing effects on PNIPAM and egg white. The majority of substances studied has the salting-out effect on PNIPAM / water in the order NaBz $\sim \mathrm{Na}$ Cinn $<$ L-NaGlu NaFer. For NaSal and NaHum; the salting-in effect has been established. For the egg white, all additives show the salting-in effect. In PNIPAM and egg white systems, NaBz and L-NaGlu demonstrate the opposite effects. The results have been compared with the ones for binary mixtures of water/di-propylene glycol propyl ether (DPnP).

Keywords: specific ion effects, salting-in, salting-out, transition temperature (TT), egg white, and Poly(Nisopropylacrylamide).

Citation: Tsurko, E. N., and Kunz, W. Salting-in and Salting-out Effects of Polyphenols, Aromatic Compounds, and Amino Acids on Poly (N-Isopropylacrylamide) and Egg White Aqueous Solutions. Sci. innov. 2021. V. 17, no. 4. P. 72-78. https://doi.org/10.15407/scine17.04.072 
Introduction. Specific ion effects [1] of large organic molecules, which are of significant importance for biophysics and medicine, are still rarely studied as compared with those of inorganic ions. However, understanding the biophysical phenomena related to the Hofmeister series or cosmotropic/chaotropic properties of ions requires corresponding thermodynamic data [2, 3].

In Patel et al. [4], it has been stated that ATP enhances protein stability. Adenosinetriphosphate (ATP) has been shown to possess the properties of hydrotrope. ATP can prevent the origin of protein aggregates, respectively, they dissolve, i.e. ATP acts as biological hydrotrope. This occurs at physiological concentrations within the range from 5 to $10 \mathrm{mmol}$.

Such studies are very important, because protein aggregates occur in many diseases, for example in brain diseases. In Alzheimer, Parkinson, and Cholea Huntington, there are formed the "unhealthy" aggregates of proteins, which coop up nerve cells or overfill the space between neurons. One other type of brain diseases arises at that time when proteins stick together and destruct nerve fibers [5]. This lead to the Prion-diseases (protein forming infectious aggregates), e.g. BSE. Prions have definite spatial 3D structure with which they are biologically active. Wrong whorled proteins cause nerve cells to die [6]. This is the cause of many processes, e.g., the mechanism of BSE transfer from ring to human.

The deficiencies of different metabolites or the supplementation of drugs could have specific effects on physiological machineries as well as nonspecific effects on protein solubility that could break processes in living body and cause diseases. This research therefore is supposed to elucidate the interactions of organic molecules in vitro by utilizing protein and protein-analog containing systems. It is interesting to study such effects and to see if additives e.g. with a polyphenol group and biologically relevant anions can interact with proteins and avoid aggregation. We have studied this issue with salting-in or salting-out ions of polyphenols, aromatic compounds, amino acids on

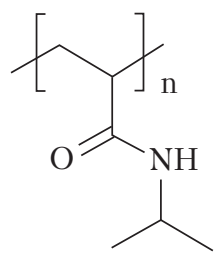

Fig. $\boldsymbol{a}$. Structural formula of PNIPAM egg white protein and on Poly $(N$-isopropylacrylamide) (PNIPAM).

$\operatorname{Poly}(N$-isopropylacrylamide) is chosen as uncharged temperature responsive polymer that belongs to Stimuli-Responsive Polymers that are also actual for the design of "intelligent materials".

PNIPAM (Fig. $a$ ) is a thermosensitive hydrogel that undergoes a coil-to-globule transition [7]. It shows a phase transition from a swollen hydrated state to a shrunken dehydrated state losing about $90 \%$ of its volume. Note that PNIPAM is used in controlled drug delivery [8].

At lower temperature, PNIPAM orders itself in solution due to enhanced hydrogen bond with the already arranged water molecules. The water molecules reorient around the non-polar regions of PNIPAM, which results in decreasing entropy $(\Delta \mathrm{S} \downarrow)$. At lower temperature, the changing Gibbs free energy is dominated by an enthalpy effect (negative enthalpy): $\Delta \mathrm{G}=\Delta \mathrm{H}-\mathrm{T} \Delta \mathrm{S}$. At higher temperature, the entropy term $(\Delta \mathrm{S}<0)$ dominates causing PNIPAM to release water and to separate the phases.

PNIPAM bears both hydrophobic (amide) and hydrophilic (isopropyl) groups. It is often used as a model system for cold denaturation of peptides and proteins [9]. In [10], with the use of a temperature gradient microfluidic device under a dark field microscope, it has been shown that LCST (the lower critical solution temperature) of sodium salts with inorganic anions ( $\mathrm{SCN}, \mathrm{I}^{-}, \mathrm{NO}_{3}^{-}, \mathrm{Br}^{-}, \mathrm{ClO}_{4}^{-}$ $\ldots \mathrm{CO}_{3}{ }^{2}$ ) and PNIPAM follows the classical Hofmeister series.

In this research, the influence of additives on Poly(N-isopropylacrylamide) that is a polymer with some similarity to proteins, egg white analog has been studied. The present research supplements a preceding one published by Grundl et al. [11]. We extend here the study of the salting-out 


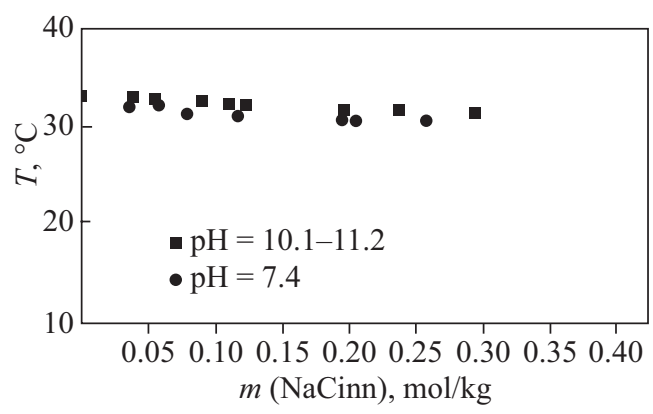

Fig. 1. Influence of sodium cinnamate additive on the TT of the PNIPAM/water system (1\%) at $\mathrm{pH}=10.1-11.2$ and $\mathrm{pH}=7.4$

and salting-in properties of organic molecules to polyphenols and aromatic compounds. These properties are considered with the use of models based on the study of the evolution of the transition temperature (TT) and of the denaturation temperature of binary mixtures of PNIPAM/water and egg white/water, respectively, with increasing additive concentration.

In our research, the temperature dependence of peptide chain unfolding has been studied in a wide temperature range. We have considered the influence of various parameters like concentration and $\mathrm{pH}$ on the thermal stability of egg white/ water and protein analog/water mixtures in the presence of additives with different structure, e.g., aromatic substances with hydrogen substituted by alkyl radical or $\mathrm{OH}$ groups in the benzene ring and made conclusions on salting-in and saltingout behavior. The stabilizing/destabilizing effect

Table 1. Influence of Humic Acid Sodium Salt Additive on PNIPAM/Water System Transition Temperature

\begin{tabular}{|c|c|c|c|}
\hline \multirow{2}{*}{$\begin{array}{c}m \text { (NaHum), } \\
\text { mol/kg }\end{array}$} & \multirow{2}{*}{$\begin{array}{c}{ }^{\circ} \mathrm{C} \\
\text { of Clouding } \\
\text { (TT) }\end{array}$} & \multicolumn{2}{|c|}{ Heating rate } \\
\cline { 3 - 4 } & & $\mathrm{T},{ }^{\circ} \mathrm{C}$ & $\begin{array}{c}\text { Time } \\
\text { hour : min }\end{array}$ \\
\hline 0 & 32.6 & $0{ }^{\circ} \mathrm{C}$ & $9: 51$ \\
0.01480 & 33.0 & $5{ }^{\circ} \mathrm{C}$ & $9: 53$ \\
0.00430 & 33.2 & $10{ }^{\circ} \mathrm{C}$ & $9: 55$ \\
0.02290 & 33.6 & $15{ }^{\circ} \mathrm{C}$ & $9: 57$ \\
0.03780 & 33.6 & $20{ }^{\circ} \mathrm{C}$ & $9: 59$ \\
0.07080 & 33.7 & $25{ }^{\circ} \mathrm{C}$ & $10: 00$ \\
0.01120 & 33.8 & $30{ }^{\circ} \mathrm{C}$ & $10: 01$ \\
\hline
\end{tabular}

of substances of various classes of different hydrophobia (polyphenols of natural origin with various structure, quinic acid, amino acids, amino acid salts, etc.) on PNIPAM and chicken egg white has been tested at $\mathrm{pH}=7.4$. The substances chosen occur in living body or in the nature. Sodium ferulate is a phenolic compound that is present in several plants with claimed beneficial effects and used for prevention and treatment of disorders associated with oxidative stress and inflammation. Sodium ferulate is constructed 5- HTReceptor as a Target. The in vitro study [12, 13] has shown inhibitory effect of sodium ferulate at the transcriptional level on the expression of some inflammatory mediators.

The other additives to PNIPAM are sodium salicylate, humic acid sodium salt, aromatic acid salts: sodium benzoate, sodium cinnamate, and tribasic amino acid salt (sodium L-glutamate). Additives to egg white: sodium benzoate, hydroxy-sodium benzoate, sodium vanillate, D-(-)-quinic acid, sodium L-glutamate, glycine, and L-alanine.

Materials. Next chemicals have been used without further purification: PNIPAM (Poly(N-isopropylacrylamide carboxylic acid terminated), Sigma Aldrich, Average Mr = 10000; sodium benzoate, Bioxtra; 3- hydroxybenzoic acid, Sigma Aldrich; vanillic acid, Sigma Aldrich; D-(-)-quinic acid, Alfa Aesar; sodium L-glutamate (monosodium glutamate monohydrate), Sigma; glycine, Sigma; Lalanine, Fluka, Sigma Aldrich;sodium salicylate,

Table 2. Influence of Quinnic Acid Additive on the Egg White/Water System Denaturation Temperature

\begin{tabular}{|c|c|c|c|}
\hline \multirow{2}{*}{$\begin{array}{l}\text { m (Q. a.), } \\
\text { mmol/kg }\end{array}$} & \multirow{2}{*}{$\begin{array}{c}\mathrm{T},{ }^{\circ} \mathrm{C} \text { of Clouding } \\
\text { (Denaturation } \\
\text { temperature) }\end{array}$} & \multicolumn{2}{|c|}{ Heating rate } \\
\cline { 3 - 4 } & & $\mathrm{T},{ }^{\circ} \mathrm{C}$ & $\begin{array}{c}\text { Time } \\
\text { hour : min }\end{array}$ \\
\hline 136.97 & 63.1 & $48{ }^{\circ} \mathrm{C}$ & $11: 29$ \\
118.99 & 62.4 & $50{ }^{\circ} \mathrm{C}$ & $11: 31$ \\
87.38 & 62.3 & $55^{\circ} \mathrm{C}$ & $11: 33$ \\
50.81 & 62.0 & $60{ }^{\circ} \mathrm{C}$ & $11: 36$ \\
24.04 & 61.7 & $65{ }^{\circ} \mathrm{C}$ & $11: 39$ \\
12.20 & 61.4 & & \\
0 & 58.1 & & \\
\hline
\end{tabular}

ISSN 2409-9066. Sci. innov. 2021. 17(4) 
Sigma; humic acid sodium salt, Sigma Aldrich; sodium cinnamate, Sigma Aldrich; trans-ferulic acid, Sigma Aldrich; sodium ferulate, Aber GmbH; salts hydroxy-sodium benzoate, sodium vanillate and sodium ferulate are obtained by neutralization of corresponding acids with sodium hydroxide (Merck); and tris(hydroxymethyl)-aminomethane, ACS Merck, buffer substance.

Experimental. 50/50 w/w mixture of egg white with buffer solution (50 mM tris(hydroxymethyl)-aminomethane (Trisbuffer), $\mathrm{pH}=7.4$ ) is prepared. Solution is centrifuged, decanted, then diluted with buffer solution (1:2), consecutively. The egg white denaturation temperature is measured by heating the solution from $48{ }^{\circ} \mathrm{C} ; 1 \% \mathrm{wt}$ PNIPAM solution is prepared, on the basis of $50 \mathrm{mM}$ Trisbuffer. For comparison, the experiment with sodium cinnamate is done at $\mathrm{pH} 10.1-$ 11.2 (Fig.1). The transition temperature is measured by heating PNIPAM solutions from $0{ }^{\circ} \mathrm{C}$.

Our data for NaSal as additive for PNIPAM solution are in good agreement with the data of Patel et al. [14]. The experiments are repeated 23 times, the example of protocol for PNIPAM is given in Table 1, for egg white in Table 2. The example of consolidated table with mean values of the TT of the PNIPAM/water systems with sodium ferulate as additive and their standard deviations is presented in Table 3.

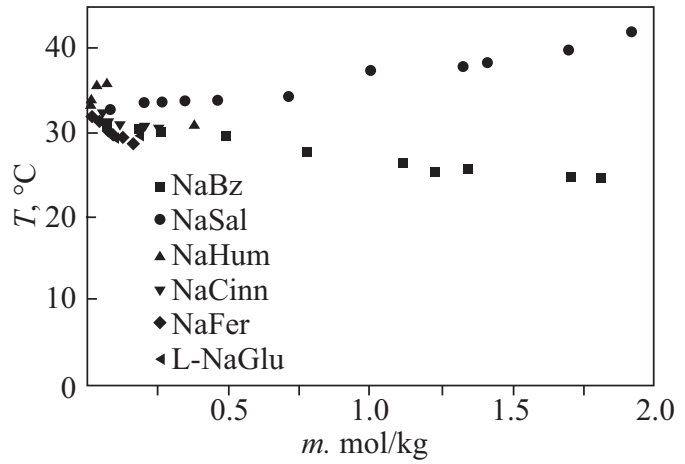

Fig. 2. Influence of the various additives on the TT of the PNIPAM/water system (1\%), $\mathrm{pH}=7.4$

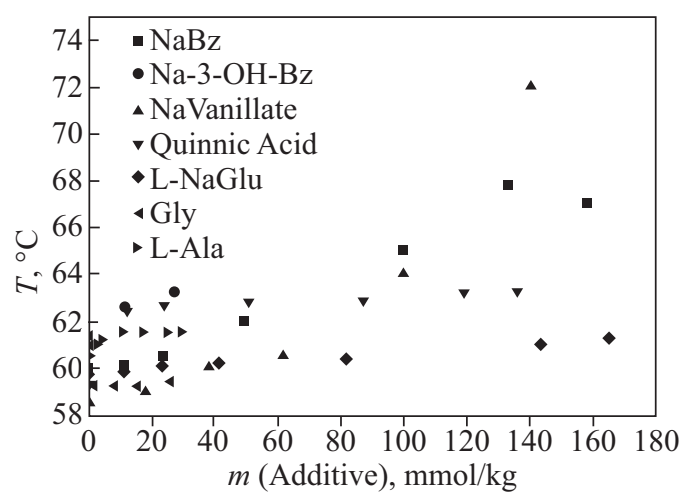

Fig. 3. Influence of the various additives on the denaturation temperature of the egg white/water system, $\mathrm{pH}=7.4$

Discussion. The majority of substances studied (sodium benzoate, sodium cinnamate, sodium ferulate, L-sodium glutamate) show the salting-out

Table 3. Transfer Temperature of the PNIPAM/Water System (1\%) with Sodium Ferulate Additive, $\mathrm{pH}=7.4$ (heating from $0{ }^{\circ} \mathrm{C}$ to $35^{\circ} \mathrm{C}$ )

\begin{tabular}{|c|c|c|c|c|c|}
\hline $\begin{array}{c}m(\mathrm{NaFer}), \\
\mathrm{mol} / \mathrm{kg}\end{array}$ & $\begin{array}{c}\mathrm{T},{ }^{\circ} \mathrm{C} \\
\text { of Clouding (TT) } \\
\text { Experiment1 }\end{array}$ & $\begin{array}{c}\mathrm{T},{ }^{\circ} \mathrm{C} \\
\text { of Clouding (TT) } \\
\text { Experiment2 }\end{array}$ & $\begin{array}{c}\mathrm{T},{ }^{\circ} \mathrm{C} \\
\text { of Clouding (TT) } \\
\text { Experiment3 }\end{array}$ & $\begin{array}{c}\text { Mean TT, }{ }^{\circ} \mathrm{C} \\
\sigma / \text { Relative Error, } \delta, \%\end{array}$ & $\begin{array}{c}\text { Standard Deviation, } \\
\sigma\end{array}$ \\
\hline 0 & 33.2 & 33.0 & 32.5 & 31.9 & $\sigma=0.35 ; \delta=1.07 \%$ \\
0.01794 & 33.2 & 32.5 & 31.2 & 31.7 & $\sigma=0.84 ; \delta=2.57 \%$ \\
0.03079 & 33.1 & 32.2 & 31.2 & 30.20 & $\sigma=0.707 ; \delta=2.14 \%$ \\
0.07673 & 32.9 & 31.1 & 30.1 & 30.00 & $\sigma=0.07 ; \delta=0.22 \%$ \\
0.08180 & 32.4 & 30.0 & 29.2 & 29.45 & $\sigma=0 ; \delta=0 \%$ \\
0.13121 & 31.9 & 29.7 & 29.0 & 29.75 & $\sigma=0.35 ; \delta=1.19 \%$ \\
0.09767 & 31.9 & 29.5 & 29.7 & 29.45 & $\sigma=0.35 ; \delta=1.22 \%$ \\
\end{tabular}




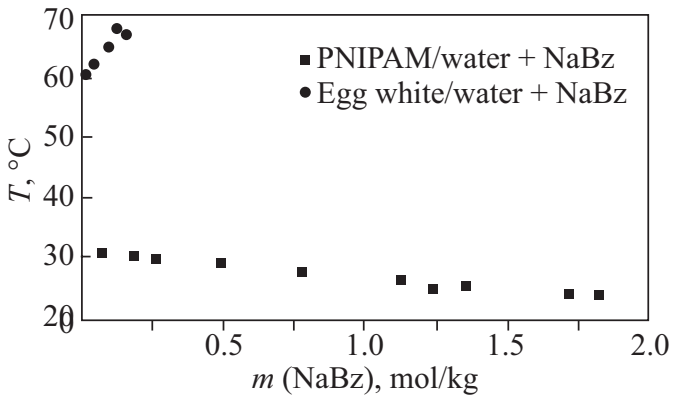

Fig. 4. Influence of sodium benzoate additive on the TT of the PNIPAM/water (1\%) and on the denaturation temperature of egg white/water system, $\mathrm{pH}=7.4$

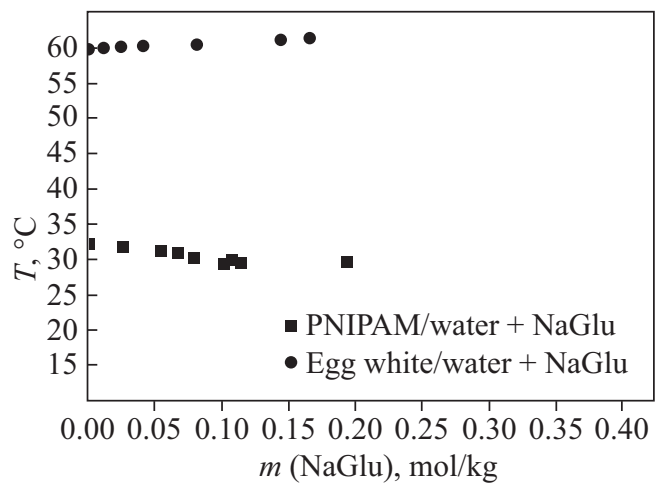

Fig. 5. Influence of sodium L-glutamate additive on the TT of the PNIPAM/water (1\%) and on the denaturation temperature of egg white/water system, $\mathrm{pH}=7.4$

effect on PNIPAM/water in the order $\mathrm{NaBz} \sim$ $\mathrm{NaCinn}<\mathrm{NaGlu} \sim \mathrm{NaFer}$ (Fig. 2). For sodium salicylate (NaSal) and humic acid sodium salt $(\mathrm{Na}-$ Hum), the salting-in effect has been established. For humus salt, this effect is even stronger than for sodium salicylate. Although, sodium humate possesses a strong dark coloration, it is easy to notice the transfer from transparent to turbid solution (by the Transition Temperature), but its low solubility does not allow studying sodium humus more precisely. The concentrations are so close, that in some cases, it is difficult to register the Transition Temperature in time for all solutions prepared.

For sodium benzoate, we have observed saltingout effect. A shift of the electron density in the benzene ring because of the presence of the hydroxyl group in sodium salicylate molecule provi- des the salting-in effect in the case of sodium salicylate. In the case of hydrogen substitution by alkyl radical in the benzene ring, the salting-out effect has been reported for sodium cinnamate and sodium ferulate.

For all egg white additives (sodium benzoate, hydroxy-sodium benzoate, sodium vanillate, D-(-)quinic acid, sodium L-glutamate, glycine, L-alanine), the salting-in effect has been reported (Fig. 3). The maximum salting-in effect has been observed for sodium benzoate, quinic acid, and sodium vanillate. For such amino acids as sodium L-glutamate and glycine, a very slight effect has been established.

From Figs. 4, 5 one can see, that in these two systems sodium benzoate and sodium L-glutamate demonstrate opposite effects: the salting-out for PNIPAM and the salting-in for egg white.

The results are compared with the ones of binary mixtures of water/dipropylene glycol propyl ether (DPnP). The same salting-out effect has been found for many amino acids (Gly, L-Ala, L-Arg, L-Pro, L-Cys) and also sodium glutamate as an additive for DPnP (dipropylene glycol propyl ether) [11]. In the case of egg white solutions, the salting-in effect has been observed. Also, the salting-out effect has been observed for adenosine phosphates (ATP $>$ ADP $>$ AMP) and also for amino acids (serine, adenosine, phosphoserine sodium salt) as additives in water/DPnP [15]. However, the effects of NaGlu on water/DPnP in Grundl research [11] are much larger than those on water/PNIPAM in our research.

Funding. E.N. Tsurko gratefully acknowledges the German Academic Exchange Service for research visit scholarship and funding provided by $R \& D$ project of fundamental studies of the Ministry of Education and Science of Ukraine.

Acknowledgements. The authors gratefully acknowledge Res. Ass. Dr. D. Touraud for the concept elaboration and fruitful discussions, $\mathrm{PhD}$ student J. Mehringer for valuable help and attention to this research. The authors are grateful to Prof. Vasiliy I. Larin for his ongoing support of this research. 


\section{REFERENCES}

1. Kunz, W. (Ed.) (2010). Specific Ion Effects. London: World Scientific.

2. Tsurko, E. N., Neueder, R., Kunz, W. (2018). Thermodynamic properties of L-aspartates of alkali and alkali-earth metals in aqueous solutions at 298.15 and $310.15 \mathrm{~K}$ and specific cation effects on biomolecule solvation. Journal of Solution Chemistry, 47(4), 727-748. doi 10.1007/s10953-018-0750-z.

3. Marcus, Y. (2012). Ions in water and biophysical implications. From chaos to cosmos. Dordrecht: Springer. doi: 10.1007 / 978-94-007-4647-3.

4. Patel, A., Malinovska, L., Saha, S., Wang, J., Alberti, S., Krishnan, Y., Hyman, A. A. (2017). ATP as a biological hydrotrope. Science, 356, 753-756. doi: 10.1126/science.aaf6846.

5. Beck, A., Anastasiadou, S., Meyer zu Beckendorf, C. (2017). Faszinierendes Gehirn: Eine bebilderte Reise in die Welt der Nervenzellen. Berlin und Heidelberg: Springer. doi: 10.1007/978-3-662-47092-3.

6. Campos, S., Machuqueiro, M., Baptista, A. M. (2010). Constant-pH Molecular dynamics simulations reveal a beta-rich form of the human prion protein. Journal of Physical Chemistry B, 114, 12692. doi: 10.1021/jp104753t.

7. Wu, C., Wang, X. (1998). Globule - to - coil function of a single homopolymer chain in solution. Physical Review Letters, 80(18), 4092-4094. doi: 10.1103/PhysRevLett.80.4092.

8. Chumg, J. E., Yokoyama, M., Yamato, M., Aouagi, T., Sakurai, Y., Okono, T. (1999). Thermo-responsive drug delivery from polymeric micelles constructed using block copolymers of poly-(N-isopropylacrylamide) and poly(butylmethacrylate). Journal of Controlled Release, 62, 115-127. doi: 10.1016/s0168-3659(99)00029-2.

9. Tiktopulo, E. I., Uversky, V. N., Lushchik, V. B., Klenin, S. I., Bychkova, V. E., Putsyn, O. B. (1995). “Domain” coil-globule transition ian homopolymers. Macromolecules, 21, 7519-7524. doi:10.1021/ma00126a032.

10. Zhang, Y., Furyk, S., Bergbreiter, D. E., Cremer, P. S. (2005).Specific ion effects on the water solubility of macromolecules: PNIPAM and the Hofmeister series. Journal of the American Chemical Society (JACS), 127, 14505-14510. doi: 10.1021/ja0546424.

11. Grundl, G., Müller, M., Touraud, D., Kunz, W. (2017). Salting-out and salting-in effects of organic compounds and applications of the salting-out effect of pentasodium phytate in different extraction processes. Journal of Molecular Liquids, 236, 368-375. doi: 10.1016/j.molliq.2017.03.091.

12. Zeni, A. L. B., Zomkowski, A. D. E., Maraschin, M., Rodrigues, A. L. S., Tasca, C. I. (2012). Ferulic acid exerts antidepressant-like effect in the tail suspension test in mice: Evidence for the involvement of the serotonergic system. European Journal of Pharmacology, 679, 68-74. doi:10.1016/j.ejphar.2011.12.041.

13. Lampiasi, N., Montana, G. (2015). The molecular events behind ferulic acid mediated modulation of IL-6 expression in LPS-activated Raw 264.7 cells. Immunobiology, 221(3), 486-493. doi: 10.1016/j.imbio.2015.11.001.

14. Patel, T., Ghosh, G., Yusa, S.-i., Bahadur, P. (2011). Solution behavior of poly(n-isopropylacrylamide) in water: effect of additives. Journal of Dispersion Science and Technology, 32, 1111-1118. doi: 10.1080/01932691.2010.497701.

15. Mehringer, J., Do, T.-M., Touraud, D., Hohenschutz, M, Khoshima, A., Horinek, D., Kunz, W. (2021). Hofmeister versus Neuberg: is ATP really a biological hydrotrope? Cell Reports Physical Science 2, 100343, February 24, 2021. doi: 10.1016/j. xcrp.2021.100343. Lizenz: CC BY-NC-ND 2.0.

Received 07.09.2020

Revised 15.02.2021

Accepted 29.03.2021

O.М. Цурко ${ }^{1}$ (https://orcid.org/0000-0001-8909-4071),

В. Куни, (https://orcid.org/0000-0002-9463-632X),

${ }^{1}$ Науково-дослідний інститут хімії Харківського національного університету імені В.Н. Каразіна,

пл. Свободи, 4, Харків, 61022, Україна,

+380 57707 5660; univer@karazin.ua

${ }_{2}^{2}$ Інститут Фізичної та Теоретичної хімії, Університет Регенсбургу,

Universitätsstr., 31, Регенсбург, 93053, Німеччина,

+49941943 4044, registratur@ur.de

ЕФЕКТИ ВСОЛЮВАННЯ ТА ВИСОЛЮВАННЯ

У ВОДНИХ РОЗЧИНАХ ПОЛІ(N-ІЗОПРОПІЛАКРИЛАМІДУ)

ТА ЯЄЧНОГО БІЛКУ ПІД ВПЛИВОМ ПОЛІФЕНОЛІВ, АРОМАТИЧНИХ СПОЛУК ТА АМІНОКИСЛОТ

Вступ. Для трактовки біофізичних явищ, пов'язаних з рядами Гофмейстера або космотропними/хаотропними властивостями іонів, необхідно мати експериментальні дані щодо іон-специфічних ефектів великих органічних молекул. 
Проблематика. Специфічні іонні ефекти мають істотну важливість для біофізики і медицини. Представляє інтерес з"ясувати, чи можуть добавки, наприклад, речовин з біологічно доречними аніонами взаємодіяти з протеїнами та уникати агрегації.

Мета. Дослідження ефектів стабілізації/дестабілізації в системах полі( $N$-ізопропілакриламід) (PNIPAM)/вода, яєчний білок/вода під впливом сполук різних класів, що відрізняються гідрофобністю.

Матеріали і методи. Матеріали: солі натрію: саліцилат, ферулат, бензоат, ванілат; натрієва сіль коричної кислоти, натрієва сіль гумусової кислоти, гідроксибензоат натрію, гліцин, L-аланін, L-глутамат натрію, D-(-)-хінна кислота, PNIPAM, яєчний білок. Методи: вимірювання температури переходу (ТT) бінарних сумішей PNIPAM/вода і температури денатурації систем яєчний білок/вода.

Результати. Іон-специфічні ефекти досліджено з використанням моделей, заснованих на вивченні еволюції температури переходу (ТT) бінарних сумішей PNIPAM/вода (при нагріванні від 0 до $35^{\circ} \mathrm{C}$ ) і температури денатурації систем яєчний білок/вода (при нагріванні від 48 до $65^{\circ} \mathrm{C}$ ). Одержано залежності температур від вмісту субстанцій, що зустрічаються в живій природі, при $\mathrm{pH}=7.4$.

Висновки. Результати демонструють тенденції ефектів солюбілізації добавок на PNIPAM і яєчний білок. Більшість досліджених сполук показує ефект висолювання на систему PNIPAM/вода в порядку NaBz $\sim \mathrm{NaCinn}<\mathrm{L}-\mathrm{NaGlu} \sim \mathrm{NaFer}$. Для NaSal та NaHum виявлено ефект всолювання. Для яєчного білку всі добавки спричиняють ефект всолювання. У системах PNIPAM та яєчного білку NaBz та L-NaGlu показують протилежні ефекти. Результати порівняно з висновками для бінарних сумішей вода/діпропіленгліколя пропіловий ефір (DPnP).

Ключові слова: іон-специфічні ефекти, всолювання, висолювання, температура переходу(ТT), яєчний білок, і полі( $N$-ізопропілакриламід). 